\title{
Election quality and international observation 1975-2004: Two new datasets* $^{*}$
}

Judith Kelley and Kiril Kolev

Duke University

Kelley, Judith G. and Kolev, Kiril, Election Quality and International Observation 1975-2004: Two New Datasets (October, 19 2010). Available at SSRN: http://ssrn.com/abstract=1694654

Word count: 5985

Jkelley@duke.edu

\section{Draft paper}

This paper introduces two new datasets on national level elections from 1975 to 2004. The data are grouped into two separate datasets, the Quality of Elections Data and the Data on International Election Monitoring. Together these data sets provide original information on elections, election observation and election quality, and will enable researchers to study a variety of research questions. The datasets will be publically available and are maintained at a project website: www.duke.edu/web/diem.

* This work is based on work supported by the National Science Foundation under Grant No. 0550111. Any opinions, findings, and conclusions or recommendations expressed in this material are those of the author and do not necessarily reflect the views of the National Science Foundation. 
Bibliographic statements:

Judith Kelley is associate professor of public policy and political science at Duke University

Kiril Kolev is a doctoral student in political science at Duke University

\section{Introduction}

This paper introduces two new datasets on national level elections created by the Project on International Election Monitoring. These new datasets will help researchers study a variety of questions. Both data sets focus on legislative and presidential elections and provide data on the election, including detailed data on its conduct. The major differences between the datasets are the level of observation, the coverage, and their sources: The Dataset on International Election Monitoring, DIEM, is based on reports issued by nineteen international organizations and is recorded at the level of individual election monitoring missions. The Quality of Elections Dataset, QED, is based on U.S. State Department reports and is recorded at the level of individual elections. Between them they cover 30 years of elections, from 1975 to 2004.

This paper first highlights the usefulness of the data by discussing some possible research applications. It then reviews the most relevant existing datasets and compares them to the DIEM and QED datasets. It then introduces the scope and variables of the data, and provides some interesting descriptive overviews. It ends by discussing the coding process and the quality of the data and stressing some issues that are important to understand before using the data.

\section{Some Possible Research Applications}

Scholars agree on the importance of elections (Dahl 1971; Przeworski, Alvarez et al. 2000). Indeed, research on elections has increased in recently years, and the new DIEM and QED datasets can be helpful to a variety of research questions.

For example, more scholars are asking questions about what role elections play in the development of a country's democratic system (Kumar 1998; Schedler 2002b; Lindberg 2009). How does the holding of elections influence other factors that may contribute to democratization? What facets of elections matter? Do certain aspects of election quality precede other pro-democratic reforms or in fact foster and encourage them (Diamond 1996)? Does moving beyond a certain level of electoral competitiveness lead to a breakdown of electoral authoritarian regimes (Lindberg 2006)? Are certain aspects of the electoral process more essential for countries in transition to solidify before becoming fully democratic? 
Thus, merely knowing whether elections are held is insufficient. To make meaningful progress in the study of the role of elections, the more detailed information the new datasets offer can be highly useful.

Studies that focus on domestic politics can also use the new election quality data to examine how electoral fortunes of certain parties or voter groups fluctuate as the integrity of the polling process changes. Research by Kurzman and Naqvi, for instance, using the new datasets, shows that competitive campaign periods with more alternatives lead to decline of support for militant Islamic parties in Egypt, Palestine and Turkey (Kurzman and Naqvi 2010). Given the ongoing debates about the role of elections in managing inter-group differences and conflict (Horowitz 1985; Lijphart 1999; Reilly 2001; Norris 2004; Birch 2007) the data sets can be used to study how election quality affects minority representation. The new datasets could also be used to study election quality influence voter behavior (Simpser 2004) or politically engagement more broadly.

Finally, the data sets are particularly useful in the emerging inquiry into international election monitoring. The DIEM mission level data can be used to study differences between organizations, nongovernmental and intergovernmental, and in combination with the QED, to address many questions about the role and effects of the presence of international observer organizations and their activities. Kelley has already used the data to begin to explore several such questions about the changing global election norms, the biases of monitoring organizations and the challenges posed by the crowed election observation field (Kelley 2008; Kelley 2009b; Kelley 2009a).

\section{Related Existing Data}

Emerging or existing data that relate to the new datasets fall into three categories: 1) data on the quality of democracy more broadly, 2) data on political and institutional attributes of elections, and 3) detailed data on the conduct of elections. Much data exist in these categories, so the discussion below is cursory.

\section{Democracy measures}

A valid challenge to the new datasets is to wonder why they are really needed when several democracy measures already exist. However, the new data can add valuable detail to studies using these broader democracy measures. The variables in POLITY, for example, one of the most frequently used standard datasets on democracy (Marshall and Jaggers 2007), aggregate several variables into an overall index. Some of the subcomponents relate closely to the electoral process, because they code the process of selecting a chief executive, political competition and opposition, and more. Scores on the subcomponent variables are made available separately. Yet, most of the variables tap into legal restrictions on having free and fair elections. Only one variable - competitiveness of executive recruitment contains information about the procedural quality of the electoral process, but this focuses solely on whether there are at least two or three viable competitors.

Another common democracy dataset is the Freedom in the World data, which contains two subcomponents, political rights and civil liberties, and an overall assessment of whether a country's freedom. The political rights variable evaluates three main dimensions: the electoral process, political 
pluralism and participation, and the functioning of government. However, these subcomponents are not very detailed and have been released only since 2006. This makes it difficult to use the political rights measure to evaluate detailed aspects of the electoral processes, since it mixes governance with regulatory and procedural aspects of elections.

In short, neither data set provides details about issues such as intimidation of candidates, restrictions on media, lack of administrative capacity, ballot-box stuffing and other procedural violations. Several other important democracy datasets exist, but they tend to share these characteristics. Thus, they provide useful omnibus measures of democracy, but they cannot be used for research concerned with more detailed aspects of elections.

\section{Data on institutions and elections}

Several recent datasets also describe institutional or political attributes of elections. For example, the Institutions and Elections Project (IEP) at Binghamton University details the legal framework surrounding and election and offers basic data on elections type, boycotts and protests (Regan and Clark no date). Another potentially useful dataset is the National Elections Across Democracy and Autocracy (NELDA), which is still under construction. It will cover multiple attributes of the elections, such as boycotts or protests, and power transfers. It will also evaluate intentions of incumbents to give up power and predictions about whether elections would be free and fair. Regarding the actual conduct of the election, however, it contains just on overall measure of whether Western monitors alleged fraud (Hyde and Marinov 2009). The same is true for the Database on Political Institutions (DPI) created by the World Bank (Beck, Clarke et al. 2001). It covers a wide array of institutional variables such as legislative and executive political competitiveness. DPI also contains a measure of extra-constitutional irregularities, but this measure conflates fraud, intimidation and boycotts and takes opposition allegations serious, even if unsubstantiated by international observers. ${ }^{1}$

Thus, these data sets offer more detail on elections than the general democracy measures. However, aside from IEP's coding of electoral rules, they do not offer detailed information about the conduct of the elections. They do not differentiate different types of irregularities, nor record the conduct of the pre-election and election-day period. They therefore are better complements than substitutes for the new QED and DIEM datasets.

\section{Data on the conduct of elections}

Several efforts to gather specific election quality data are underway. Some regional studies discuss election quality (Bratton 1998; Lindberg 2006). In-depth post-election evaluation or audits are also becoming more common, but remain ad hoc, as for example after the 2007 elections in Kenya. Furthermore, these are not quantified. However, some scholars and practitioners have begun efforts to systematize data gathering after elections. One example is Jørgen Elklit and Andy Reynolds' Election Quality Assessment Project which has over 50 quality indicators (Elklit and Reynolds 2005). However, these important efforts are all emergent or in pilot stages, and therefore their coverage is still sporadic.

\footnotetext{
1 "Recording is irrespective of whether only opposition claims that fraudulent elections have occurred or whether allegations are backed by independent international observers (Keefer 2002 18.)"
} 
Steven Fish's e-parliament election data collects quite detailed data, but is confined to parliamentary elections and covers only the most recent elections as of 2009 (Fish 2009). The broadest coverage is the Electoral Malpractice and Electoral Manipulation dataset by Sarah Birch (Birch 2009), which contains an index of election quality, based on fifteen questions. However, this data only covers Central and Eastern European countries and few countries in Latin America and Africa between 1995 and 2006 and includes only 137 elections. The data relies exclusively on reports by the European Union, the Organization of American States, and the Organization for Security and Co-operation in Europe, and is therefore only available for monitored elections. Thus, DIEM and QED offer more comprehensive coverage than any existing dataset on the conduct of elections. Comparison with existing datasets is difficult, because their coverage is smaller or covers different years and the variables are not the same.

\section{The Quality of Elections Dataset}

The QED data covers elections from 1975 to 2004. The election quality variables are based on 1,202 reports from the US State Department Reports on Human Rights Practices and draw especially, but not exclusively, from the section on the "Rights of Citizens to Choose Their Governments." These reports only date back to 1977, but based on other sources, as noted later, the QED also includes data on other characteristics of elections, thus going back to 1975 .

The QED makes three main contributions. First, it assembles a comprehensive list of national level elections since 1975. When the project began, no such list existed aside from the DPI, which still omitted many elections. Second, it includes variables on the presence of monitors from 1975 to 2004, specifically coding individual organizations. New data is also being added on turnover, boycotts, post-election violence and several other election attributes. Third, it complements the DIEM data by including similar measures of election quality. The first two of these contributions is discussed below, and the election quality variables are discussed later jointly with the DIEM election quality variables.

QED assembles a comprehensive list of direct national legislative, presidential and general elections based on a multitude of sources such as Elections Today, a series of articles in Journal of Democracy and National Elections, a similar series in Electoral Studies. Internet sources included the Lexis Nexis database, the Database on Political Institutions by the World Bank (Beck, Clarke et al. 2001), the African Elections Database (African Elections 2008), the Election Guide (IFES 2010), Elections Around the World (Electionworld 2010), Election Resources on the Internet (Alvarez-Rivera 2010), Adam Carr's Election Archive (Carr 2010), the Parline database (Inter-Parliamentary Union 2010), among others. The resultant list of elections is one of the most comprehensive available and includes 1,324 elections. In addition to type, it includes the year and month of each election. Run-offs are coded as part of the original election, but multiple elections in one year receive separate entries.

The QED also provides data on the presence of international monitoring organizations. Of the 1,324 elections in the data, 442 elections were monitored by 922 missions. A monitoring mission is defined as the presence of a formal monitoring delegation from an international agency on the day(s) of the election. Smaller national delegations or local embassy activities are not counted, because they are ubiquitous and their observations usually remain internal. Missions of pure technical assistance (such as 
the OAS mission in Argentina in 2003, UN or IFES electoral assistance efforts, or CAPEL ${ }^{2}$ missions more generally) are also not considered monitoring events. Pre-election missions that leave before the day of the election and are not followed by another delegation to be present for the polling day itself are also not counted as monitoring. The monitoring information is based on the activities of 21 formal organizations involved in monitoring either presently or historically, as shown in Table 1, as well as a category for "others," which facilitates the inclusion of major ad hoc monitoring efforts, such as in Kenya in 1997 when a consortium of international donors monitored the election.

Table 1 here

This data significantly upgrades the scattered and inconsistent information hitherto available. Thus, it was often necessary to communicate directly with each organization, because final reports were unavailable, and many websites provided incomplete or inconsistent information. Getting the record straight sometimes required months of digging by the organizations themselves in response to a request, and sometimes they corrected their websites afterwards. In addition, every election was searched in the LexisNexis database for mentions of international observers or monitors, or the names of organizations specifically. These stories were then read to ascertain whether they were indeed monitored. In addition to indicator variables for each of the organizations, there is an indicator of whether any organization was present. Figure 1 below illustrates how election monitoring has risen over time from no elections being monitored in 1975 and 1976 to over 50-60 percent of all elections being monitored in the latter years of the dataset.

Figure 1 here

In addition, the QED also includes measures on several other election characteristics such as whether the election was a first multiparty election, a post conflict election, a post coup election, whether the election lead to a turnover of power, whether it prompted boycotts, or was followed by violence. Coding of these variables drew on the election monitoring reports and the US State Department Reports, but was also supplemented with information from SIPRI's conflict data, ${ }^{3}$ the Archigos dataset, ${ }^{4}$ and several of the election sources discussed above.

\footnotetext{
${ }^{2}$ El Centro de Asesoría y Promoción Electoral (CAPEL) is an organization active in Latin America.

${ }^{3}$ http://www.pcr.uu.se/research/UCDP/index.htm. Last accessed May 13, 2009.
} 
The QED also codes the statements in the US State Department reports about the freedom of association in a country, the freedom of speech, and the freedom of citizens to change their government. The code book describes the coding scheme for these variables.

\section{The Data on International Election Monitoring}

The DIEM codes information from 592 reports by $19^{5}$ organizations that covered 306 elections in 109 countries from 1980 to 2004. Because international monitors rarely visit highly autocratic states and only recently have begun to visit established democracies, the elections in the DIEM tend to be in countries in the middle of the democracy spectrum. However, these are often the transition countries and the detailed information can therefore be particularly useful.

DIEM contributes, first, by providing detailed information on the activities of international election monitors, and second, by providing three levels of data on election quality, two of which overlap with the QED data.

The coding of the election monitoring documentation captures several attributes of the election monitoring mission: the size and date of different delegations, the number of pre-election visits, the number press statements, and the number of pages in various forms of documentation such as final reports and post election statements. The data also tracks whether monitors engaged in various activities such as direct observation of the polling, logistical support, observation of campaign rallies, provision of training of domestic monitors, civic education, legal advice, media monitoring, among others. Individual missions have sent as many as 2000 observers, stayed in country for nearly a year, and some have written reports as long as 216 pages. Figure 2 provides an overview of activities, and reveals, among other things, that international organizations rarely conduct quick-counts, which, although expensive, are probably quite powerful (Garber and Cowen 1994). Furthermore, 40 percent of missions make pre-election visits, which are important to discuss many of the more structural and institutional challenges in an election. Most organizations pay attention to media, but only about one in five conduct formal, systematic analysis.

Figure 2 here

Like QED, DIEM also includes several of the identifiers used the QED data, such as the data and type of election, in addition to ID variables that enables facilitate data merging.

4 Thanks to Hein Goemans for providing early access to this data. See http://mail.rochester.edu/ hgoemans/data.htm. Last accessed February 1, 2010.

${ }^{5}$ Only a few reports from the AU were coded, and none from ECOWAS. La Francophonie were only coded for presence and overall assessment. 


\section{Election quality variables in QED and DIEM}

The QED and the DIEM complement each other by including similar measures of election quality. The QED covers more elections, but the level of detail is significantly lower than in the DIEM, because the state department coverage of elections is usually much briefer than that of election monitoring reports. Thus, the average number of pages on elections contained in the State Department reports was 3.4, compared to 38.9 in election monitoring reports used for DIEM. Subsequently QED covers the same main variables, but does not cover as many sub-variables as DIEM.

\section{Conceptualization the election quality variables}

It is crucial to stress that the assessments of election quality are not objective and true measures of election quality. Rather, they are quantifications of the opinions stated by the sources. That is, in DIEM, the variables quantify the assessment of the individual international observer group. In QED, the variables quantify the assessment of the US State Department. At best these measures therefore proxy for actual election quality, and they should be discussed as such when analysts use them.

There is an extensive debate about how to measure election quality. This project does not solve that debate, but simply provides details on a number of subcomponents of elections as reported by the sources. However, some decisions were nevertheless necessary to create the categories and rules for coding. Indeed, hundreds of categories could easily have been created and would have made coding simpler in some ways, but use of the data too unruly. Thus, simplifying rules were a necessary evil. To establish the categories for coding, this project drew on the work of several detailed and careful academic works about the nature of election irregularities (Elklit and Svensson 1997; Elklit 1999; Elklit and Reynolds 2002; Schedler 2002a; Lehoucq 2003; Elklit and Reynolds 2005). In addition the project also drew on organizational documents about electoral standards (International Institute for Democracy and Electoral Assistance 1995; OAS 2007; OAS 2008; Commission of the European Union Undated), and treaty standards, many of which are elaborated in an extensive compendium compiled by the European Union (European Commission 2007).

\section{Variable Description}

The election quality variables contained in the DIEM and QED datasets can be divided into three increasingly detailed layers, the top two of which are shared by both data sets, and the last of which is covered only by the DIEM. The three layers are: 1) overall assessments, 2) main categories of irregularities, and 3) sub-categories.

\section{Overall assessments}

There are two overall assessment variables. The first captures whether the source indicates that the election was acceptable or not. The second captures the organizations' description of the extent of the problems in the election. Both are ordered variables and coded as described in Table 2 below. The online codebook contains more details. 
Table 2 here

However, DIEM and QED differ in their coding method for these two variables, and it is important to beware of this difference given that the variables essentially appear to be identical. In the QED the variables use all the available information in the report to assess the election as accurately as possible. In contrast, because of the inquiry that motivated the creation of the data, the purpose of the overall assessment variables in DIEM is to code the summary assessment of the monitoring mission - that is, what does the mission choose to conclude about the election? Reading of the reports showed that monitoring organizations were often more critical in later reports than in statements immediately after the election, or that their summary introduction or conclusion in the reports were more favorable than the content of the report would seem to justify (Kelley 2009a). Because these summary statements get the most attention both in the media and from other governments, the DIEM project sought to capture these evaluations. Thus, coders were trained to first code these two overall assessment variables by drawing exclusively on press statements, preliminary statements, the introduction/executive summary or conclusion of the report only, before even reading the body of the report. Because of these coding differences, QED is better suited for simple measures of election quality. Alternatively, to take advantage of the greater level of details in election reports, analysts can for example use the strictest assessment by any monitoring organization present as done in some analysis (Kelley 2009a).

Figure 3 and Figure 4 here

Figures 3 and 4 show the distribution of the two overall assessment variables in the data sets. A few things are worth noting: First, the data do not describe the same elections: The DIEM data codes a tougher sub-set of elections, and elections monitored by more than one mission are represented once for each organization present. Second, in Figure 3, the 'ambiguous' category is less used than the other categories, especially in the QED. Users of the data need to consider these distributions and may, depending on their analysis, either omit ambiguous cases altogether, include them, or collapse them with one of the other categories. Still, the figures reveal interesting information. According to the QED, for example, about two-thirds of all elections since 1975 have been "acceptable." Further analysis reveals a slight increasing time trend in this data as many countries have improved, but many nondemocracies also have begun to hold elections. 


\section{Main and sub-categories}

Table 3 below shows the main categories and subcategories of the data. These are all coded on a 0-3 ordered scale equivalent to that of the "Extent of the problems," shown in Table 1.

Importantly, just as the overall assessments discussed above, each of these variables are coded individually. None is an index that simply aggregates subcomponents. Such indices could be created, but it is not advisable, because these irregularities are qualitatively very different and the ordered nature of the data makes simple addition of subcomponents problematic. Thus, such indices would suffer from construct validity.

Table 3 here

The main components cover four areas: legal problems, cheating, administrative problems, and violence. The three latter are further recorded separately for the pre-election period and the Election Day (including post-election processing). Violence is physical force that is directly related to the election. Non-physical events (such as threatening a voter with job loss) are coded as intimidation and therefore considered a form of cheating, not a form of violence. The difference between the cheating and the administrative categories whether the behaviors imply intent to systematically manipulate the outcome. Intent is naturally not knowable, but certain behaviors suggest greater intent than others.

For the behaviors classified as cheating intent is reasonably certain. Politicians do not intimidate voters by accident. Vote-buying is not a product of undeveloped logistical capacity. Reporting more votes for the incumbent than turnout justifies is not because the election officials cannot count. Similarly, incumbents do not dominate media because no contrary voices exist, they do not ban campaign rallies for lack of open spaces, nor do they fund their campaigns from government coffers because they forgot to open a separate bank account. Rather, these behaviors are indented to manipulate the outcome.

In contrast, the intent of the behaviors classified as administrative are more ambiguous. Failure to inform voters of their polling station locations could be intentional, but it could also be because the information is difficult to get out. Problems in voter lists could be systematically manipulated to favor some parties and politicians, but they could also be due to problems with processing paper work. Lack of professionalism or even neutrality on the electoral commission could be planned, but it could also be due to lack of training and experience. Not ensuring that voters have full secrecy or that campaign materials are kept at a proper distance from the polling station could be abusive, but such problems could also be administrative errors. Thus, these problems could be intentional, but they could also stem from lack of capacity or experience.

It is important to point out that the variable labels do not exhaust the list of things that coders were cognizant of when making their judgments. For example, the legal framework variable also considered the lack of universal franchise, flaws in the complaints procedures, inadequate campaign finance 
legislation, and all sorts of other regulation. Likewise, voter fraud also included, inter alia, double voting, vote buying, and voter impersonation. Again, the code books contain more information on both the main components and the sub-components.

Figure 5 shows the distribution of the main categories in the QED data. This distribution is quite different from what a Figure of the DIEM data would look like, because nearly half of the elections in the QED data are in countries rated free by Freedom House. However, Figure 5 reveals, inter alia, that legal problems and cheating in the pre-election period are the most commonly reported forms of irregularities in the State Department reports.

Figure 5 here

\section{Potential Biases}

To quantify complicated information, datasets necessarily oversimplify. They also are subject to human error. Most importantly, they are no better than the sources on which they rely. These new datasets are no different, and users therefore must be aware of the weaknesses as well as the strength of the data.

First, it is important to reiterate that electoral problems are difficult to fully uncover, and the data sets are not full accounts of fraud. Rather, they quantify what international monitoring organizations and the US State Department has chosen to report. Both the monitoring organizations and the US State Department have organizational biases. Monitoring organizations consider more than a rigid checklist to evaluate an election. They are cognizant of their own institutional needs and of the possible consequences of their statements. Thus, they may tone down their criticisms (Kelley 2009a). On the other hand, monitors may become more critical after multiple visits if a country continues to falter. Similarly, the State Department likely reflects some U.S. foreign policy preferences. Although such criticism of the reports lessened after the early years after research found the bias to be small, ${ }^{6}$ this is important to recall. The State Department reports were nevertheless used because they are some of the most comprehensive and consistently available documents. Staying with one consistent source makes it easier for others to replicate coding and for everyone to evaluate and understand how possible biases may influence analysis.

Second, analysis shows some time trends in the data. Some of these likely reflect actual trends around the world. However, criticisms may also have increased over time simply because more extensive information became available. For example, although election monitoring reports stay the same average length, state Department report gets longer over time. In any case, it will be prudent to control for time trends when using the data, and if using the data to consider changes over time, these time biases in the data should be considered.

${ }^{6}$ Poe, et al. 2001. 
Third, there is some "contamination" between the two datasets, because the US State Department relies on official election monitoring reports as one of several sources. Thus, 29 percent of the State Department reports mention the assessment of international observers. This may mean again that the State Department has more information on monitored elections, and therefore may be more critical of these.

The good news is that the coding processes produced quite consistent coding. The coders were trained extensively through the coding and discussion of numerous test-documents and their instructions are posted on the data website. Most of the coding occurred in a full-time work setting where coders were working in the same room. Two coders, at least one of which was a doctoral student, independently coded all materials. After this, any differences were reconciled, if necessary with the help of the Principal Investigator. To get an impression of how consistent the coders were before reconciling, each dataset contains measures of inter-coder reliability prior to reconciliation. The scores calculate the average agreement for each level of election quality variables. As Table 4 shows, agreement ranged from 83.1 to 92.8 percent.

Table 4 here

\section{Summary}

These two dataset provide scholars with new tools to analyze election quality, and the role of elections in domestic governance. With their global coverage, they provide far greater detail about the actual conduct of election than existing datasets. The discussion in this article helps potential users understand the data and illustrates how informative the data can be. Scholars wishing to use the data should consult the project webpage, manuals and codebooks, and are welcome to discuss any questions with the authors. 


\section{Tables and Figures}

Table 1: Number of missions by international monitoring organizations to legislative and executive elections, 1975-2004

\begin{tabular}{|llr|}
\hline Acronym & Full name & Missions \\
\hline OSCE & The Organization for Security and Cooperation in Europe & 124 \\
COE & Council of Europe & 77 \\
OAS & The Organization of American States & 71 \\
NDI & National Democratic Institute & 58 \\
IRI & International Republican Institute & 63 \\
OIF & Organisation internationale de la Francophonie & 60 \\
EP & The European Parliament & 59 \\
AU & African Union & 48 \\
CW & The Commonwealth Secretariat & 46 \\
UN & United Nations & 47 \\
IFES & The International Foundation for Election Systems & 38 \\
EU & European Union & 42 \\
CC & The Carter Center & 41 \\
CIS & Commonwealth of Independent States & 14 \\
IHRLG & The International Human Rights Law Group & 14 \\
NHC & the Norwegian Helsinki Center & 12 \\
ANFREL & The Asian Network for Free Elections & 12 \\
ECOWAS & The Economic Community of West African States & 11 \\
SADC & The South African Development Community & 11 \\
ECF & Electoral Commissions Forum & 8 \\
EISA & The Electoral Institute of South Africa & 7 \\
& Other organizations & 59 \\
\hline TOTAL & & 922 \\
\hline
\end{tabular}

Table 2: Overall Election Evaluations

\begin{tabular}{|l|ll|}
\hline Acceptability & 1 & $\begin{array}{l}\text { The organization states that the election represents the will of the } \\
\text { voters, is free and fair, or in other ways frankly endorses the } \\
\text { outcome }\end{array}$ \\
\hline & $\begin{array}{l}0.5 \\
\text { The organization is entirely ambiguous, outright states that it has no } \\
\text { opinion, or is simply silent }\end{array}$ \\
\cline { 2 - 4 } & $\begin{array}{l}\text { The organization explicitly states that the election does not represent } \\
\text { the will of the voters, is not free or fair, or otherwise delegitimizes } \\
\text { the outcome of the election }\end{array}$ \\
\hline Extent of problems & $\begin{array}{l}\text { No problems } \\
\text { Minor problems } \\
\text { Moderate problems }\end{array}$
\end{tabular}


\begin{tabular}{l|ll} 
& 3 & Major problems
\end{tabular} 
Table 3: Main and sub-components

\begin{tabular}{|c|c|}
\hline Main Components & Sub-components (DIEM only) \\
\hline \multirow[t]{3}{*}{ Legal framework } & Deficiencies in Legal Framework \\
\hline & Limits to scope and jurisdiction of elective offices \\
\hline & Unreasonable limits of who can run for office \\
\hline \multirow[t]{4}{*}{ Pre-election cheating } & Improper use of public funds \\
\hline & Restrictions on freedom to campaign \\
\hline & Restrictions on media \\
\hline & Intimidation \\
\hline \multirow[t]{4}{*}{ Pre-election administrative } & Problems in voter lists / registration \\
\hline & Complaints about electoral commission conduct \\
\hline & Voter information and procedural problems \\
\hline & Technical/procedural difficulties \\
\hline \multicolumn{2}{|l|}{ Pre-election violence and unrest } \\
\hline \multirow[t]{3}{*}{ Election-day explicit cheating } & Vote processing and tabulation tampering \\
\hline & Voter fraud \\
\hline & Intimidation \\
\hline \multirow[t]{4}{*}{ Election-day administrative } & Informational insufficiencies \\
\hline & Administrative insufficiencies \\
\hline & Problems in voter lists \\
\hline & Complaints about electoral commission \\
\hline \multicolumn{2}{|l|}{ Election-day violence and unrest } \\
\hline
\end{tabular}

Table 4: Inter-coder reliability scores

\begin{tabular}{|l|l|l|l|}
\hline & Overall assessments & Main categories & Sub-categories \\
\hline DIEM & $86.2 \%$ & 92.8 & $83.1 \%$ \\
QED & $88.5 \%$ & $89.3 \%$ & N/A \\
\hline
\end{tabular}




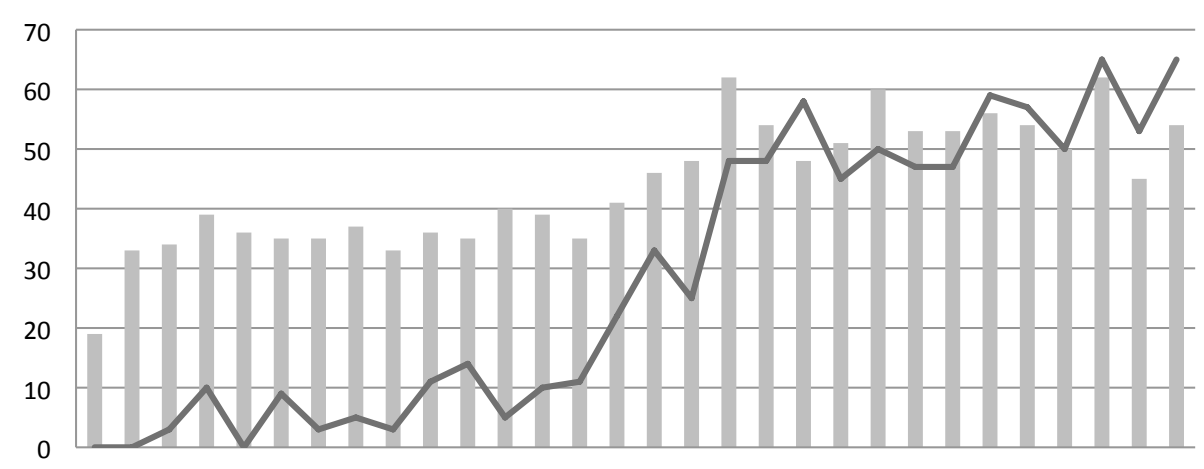

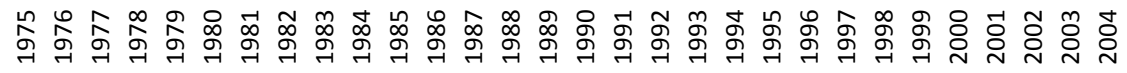

Number of Elections —Percent Monitored

\section{Figure 1: The Rise of Monitoring}

Percent of monitoring missions that:

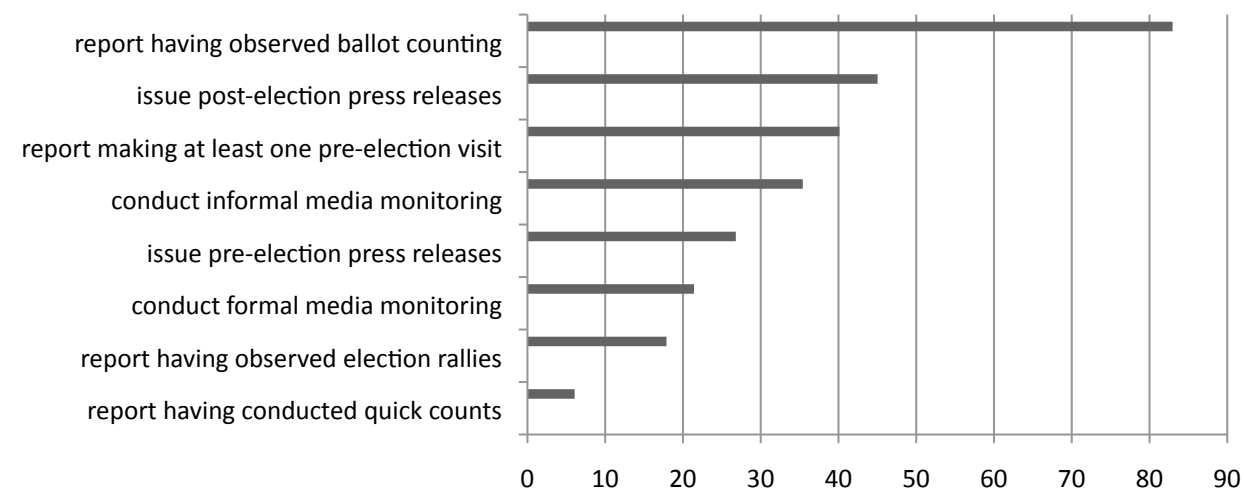

Figure 2: Frequency of monitoring activities 
Note: not including the AU, ECOWAS and OIF for which this information was not available.

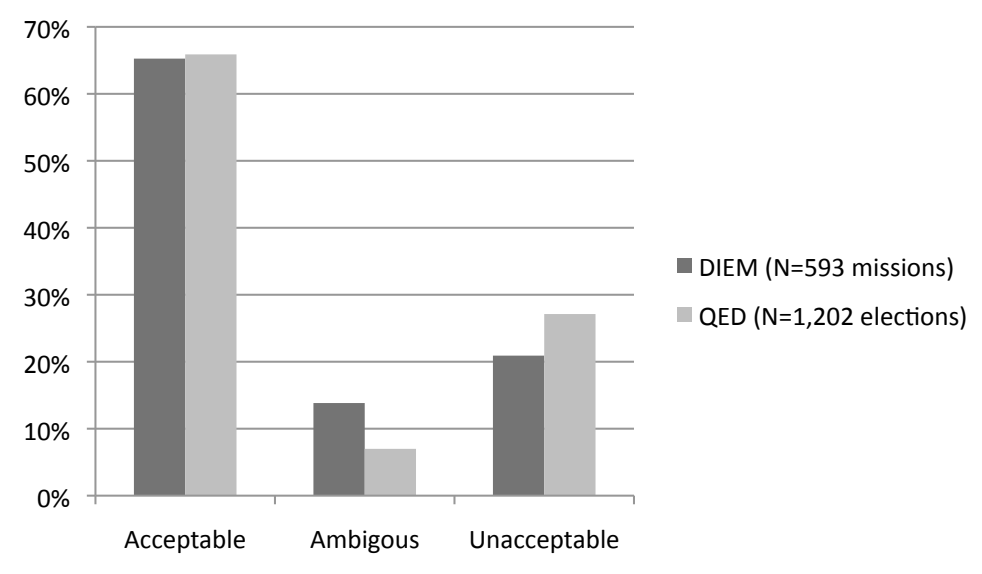

Figure 3: Distribution of "Acceptability"

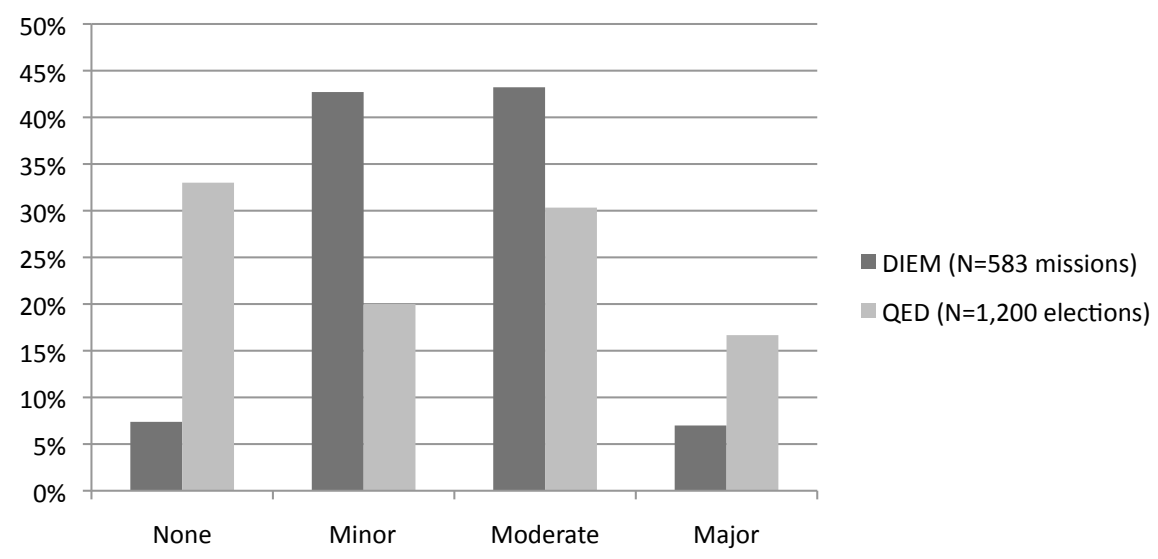


Figure 4: Distribution of "Extent of Problem"

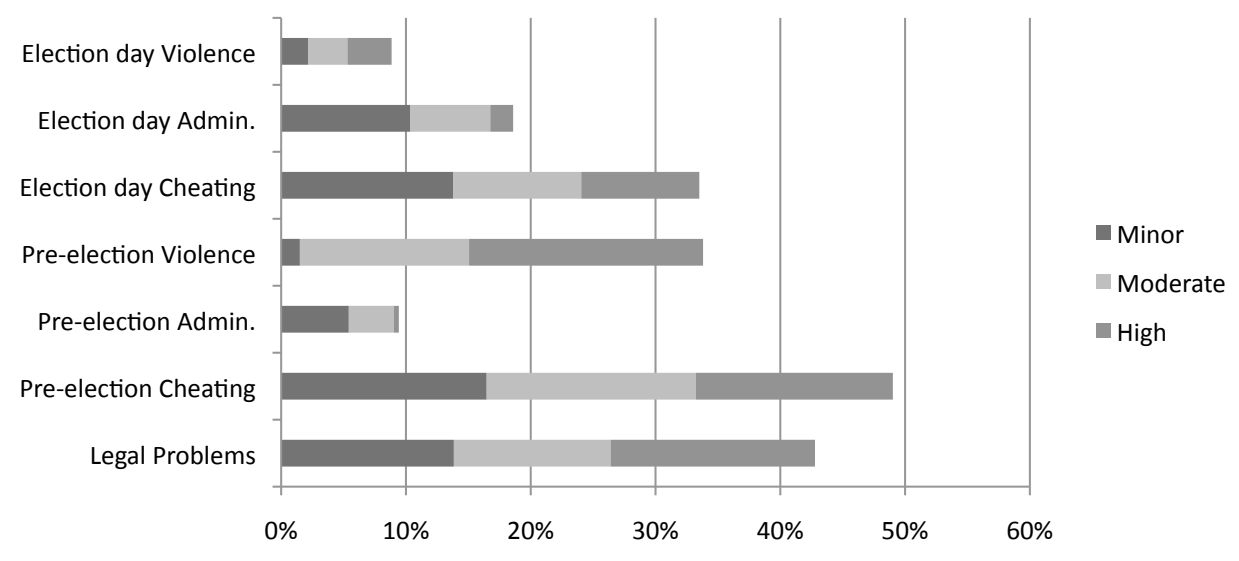

Figure 5: Distribution of main categories in QED 


\section{References}

African Elections. (2008). "African Elections Database." from http://africanelections.tripod.com/.

Alvarez-Rivera, Manuel. (2010). "Election Resources on the Internet." Retrieved 2/23/2010, 2010, from http://electionresources.org/.

Beck, T, G Clarke, et al. (2001). "New Tools in comparative political economy: The database of Political Institutions." World Bank Economic review 15: 165-176.

Birch, Sarah (2007). "Electoral Systems and Electoral Misconduct." Comparative Political Studies 40(12): 1533-1556.

Birch, Sarah (2009). Project on Explaining Electoral Malpractice in New and Semi-Democracies.

Bratton, Michael (1998). "Second elections in Africa." Journal of Democracy 9(3): 51.

Carr, Adam. (2010). "Adam Carr's Election Archive." Retrieved 2/23/2010, 2010, from http://psephos.adam-carr.net/about/about.shtml.

Commission of the European Union. (Undated). "Reporting Guidelines." Retrieved March 13, 2008, from http://ec.europa.eu/external relations/human rights/election observation/docs/2007 eu eo $\underline{m}$ reporting guidelines en.pdf.

Dahl, Robert Alan (1971). Polyarchy; participation and opposition. New Haven,, Yale University Press.

Diamond, Larry (1996). "Is the Third Wave Over?" Journal of Democracy 7(3): 20-37.

Electionworld. (2010). "Electionworld." Retrieved 2/23/2010, 2010, from http://en.wikipedia.org/wiki/User:Electionworld/Electionworld.

Elklit, Jørgen (1999). "Electoral institutional change and democratization: You can lead a horse to water, but you can't make it drink." Democratization 6(4): 28 - 51.

Elklit, Jorgen and Andrew Reynolds (2002). "The Impact of Election Administration on the Legitimacy of Emerging Democracies: A New Comparative Politics Research Agenda." Commonwealth \& comparative politics 40(2): 86.

Elklit, Jorgen and Andrew Reynolds (2005). "A framework for the systematic study of election quality." Democratization 12(2): 147-162.

Elklit, Jorgen and Palle Svensson (1997). "What makes elections free and fair?" Journal of Democracy 8(3): 32.

European Commission (2007). Compendium of International Standards for Elections. Brussels.

Fish, Steven (2009). The e-Parliament Election Index, E-Parliament.

Garber, Larry and Glenn Cowen (1994). "The Virtues of Parallel Vote Tabulations." Journal of Democracy 4(2): 95-107.

Horowitz, Donald (1985). Ethnic Groups in Conflict. Berkeley and Los Angeles, CA, University of California Press.

Hyde, Susan and Nikolay Marinov (2009). National Elections Across Democracy and Autocracy.

IFES. (2010). "International Foundation for Electoral Systems Election Guide." Retrieved 2/23/2010, 2010 from http://www.electionguide.org/about.php.

Inter-Parliamentary Union. (2010, 2010). "Inter-Parliamentary Union PARLINE Database on National Parliaments." Retrieved 2/23/2010, 2010, from http://www.ipu.org/parlinee/parlinesearch.asp.

International Institute for Democracy and Electoral Assistance (1995). Lessons learnt : international election observation: seventeen organizations share experiences on electoral observation: a 
roundtable jointly organized by the United Nations Electoral Assistance Division and International IDEA. Stockholm, International Institute for Democracy and Electoral Assistance.

Keefer, Phillip (2002). "DPI2000 Database of Political Institutions: Changes and Variable Definitions."

Kelley, Judith (2008). "Assessing the complex evolution of norms: the rise of international election monitoring." International Organization 62(2): 221-255.

Kelley, Judith (2009a). "D-Minus Elections: The Politics and Norms of International Election Observation." International Organization 63(04): 765-787.

Kelley, Judith (2009b). "The More the Merrier? The Effects of Having Multiple International Election Monitoring Organizations." Perspectives on Politics 7(01): 59-64.

Kumar, Krishna (1998). Postconflict elections, democratization, and international assistance. Boulder, Lynne Rienner.

Kurzman, Charles and Ijlal Naqvi (2010). The Islamists Are Not Coming. Foreign Policy. Washington, DC, Foreign Policy. January/February 2010.

Lehoucq, Fabrice (2003). "ELECTORAL FRAUD: Causes, Types, and Consequences." Annual Review of Political Science 6(1): 233-256.

Lijphart, Arend (1999). Patterns of Democracy. New Haven, Yale University Press.

Lindberg, Staffan (2006). Democracy and Elections in Africa. Baltimore, MD, The Johns Hopkins University Press.

Lindberg, Staffan, Ed. (2009). Democratization by Elections: A New Mode of Transition. Baltimore, Maryland, Johns Hopkins University Press.

Marshall, Monty and Keith Jaggers (2007). Polity IV Project: Political Regime Characteristics and Transitions, 1800-2007, Center for Systemic Peace.

Norris, Pippa (2004). Electoral Engineering: Voting Rules and Political Behavior. Cambridge, MA, Cambridge University Press.

OAS (2007). Methods for Electoral Observation: A Manual for OAS Electoral Observation Missions. Washington, D.C., General Secretariat of the Organization of American States.

OAS (2008). Report: "Best Practices in OAS Electoral Observation, 2004-2007". General Committee. Washington, D.C., Permanent Council of the Organization of American States.

Poe, Steven, Sabine Carey, et al. (2001). "How Are These Pictures Different-A Quantitative Comparison of the US State Department and Amnesty International Human Rights Reports, 1976-1995." Human Rights Quarterly 23: 650-677.

Przeworski, Adam, Michael Alvarez, et al. (2000). Democracy and development : political institutions and well-being in the world, 1950-1990. Cambridge, Cambridge University Press.

Regan, Patrick Regan and David Clark (no date). The Institutions and Elections Project at Birmingham University.

Reilly, Benjamin (2001). Democracy in Divided Societies: Electoral Engineering for Conflict Management. Cambridge, UK, Cambridge University Press.

Schedler, Andreas (2002a). "The Menu of Manipulation." Journal of Democracy 13(2): 36-50.

Schedler, Andreas (2002b). "The Nested Game of Democratization by Elections." International Political Science Review 23(1): 103-122.

Simpser, Alberto (2004). Making Votes Not Count: Strategic Incentives for Electoral Corrpution, Stanford University. 